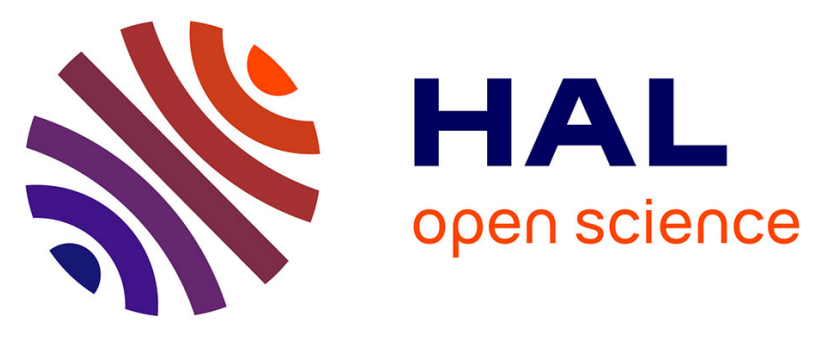

\title{
Hydro-system flow modelling for water resources management in the fractured and karstified chalk aquifer environment of Eastern Normandy
}

Didier Pennequin, Pierre-Yann David, Marie Servière, Nadia Amraoui, Christelle Loiselet

\section{To cite this version:}

Didier Pennequin, Pierre-Yann David, Marie Servière, Nadia Amraoui, Christelle Loiselet. Hydrosystem flow modelling for water resources management in the fractured and karstified chalk aquifer environment of Eastern Normandy. Eurokarst 2016, Sep 2016, Neuchatel, Switzerland. hal-01355499

\section{HAL Id: hal-01355499 https: / hal-brgm.archives-ouvertes.fr/hal-01355499}

Submitted on 23 Aug 2016

HAL is a multi-disciplinary open access archive for the deposit and dissemination of scientific research documents, whether they are published or not. The documents may come from teaching and research institutions in France or abroad, or from public or private research centers.
L'archive ouverte pluridisciplinaire HAL, est destinée au dépôt et à la diffusion de documents scientifiques de niveau recherche, publiés ou non, émanant des établissements d'enseignement et de recherche français ou étrangers, des laboratoires publics ou privés. 


\title{
Hydro-system flow modelling for water resources management in the fractured and karstified chalk aquifer environment of Eastern Normandy
}

\author{
${ }^{1 *}$ Pennequin, D., ${ }^{2}$ David, P.Y., ${ }^{2}$ Servière, M., ${ }^{2}$ Amraoui, N. ${ }^{2}$, Loiselet, C. ${ }^{2}$ \\ *lead presenter \\ 1'd.pennequin@brgm.fr, BRGM, France, ${ }^{2}$ BRGM, France
}

\begin{abstract}
Modelling complex groundwater/surface water flow in karstified chalk aquifer systems both requires appropriate modelling techniques and a good knowledge of geology and discontinuities (geological and hydrogeological). This is the case for the Avre River hydro-system for which a multi-layer geologic model was built, including geological and potential hydrogeological discontinuities, which then served as the basis to elaborate and calibrate the 3D hydro-system flow model. The latter through the calibrating process notably allowed explaining the presence of important spring arrays used for drinking water purposes in the central part of the basin, by the existence of a major impermeable intersecting faults system and highly fractured or karst conduits which developed along lineaments and faults.
\end{abstract}

\section{Introduction}

Groundwater flow in karstified chalk aquifer systems is mostly governed by fracturing, karst conduits, lithological facies changes and tectonic structures such as faults and fault systems. In addition, fractured areas and karst conduits developments often result from geological heterogeneities or discontinuities, thereby linking groundwater flow to lithology and geological structures in many instances, to some extent at least. This is particularly true in Eastern Normandy, in the northwestern part of the Paris basin, where karst channels, fractured chalk valleys (wet or dry valleys underneath which the upper part of the chalk is being intensively fractured), chalk heterogeneities and fault structures are abundant and often well developed, and many times account for dual flow systems (darcian/fractured and karstic), spring concentration aligned patterns and intensive exchange between surface water and groundwater. This has consequences notably for water resources management and pollutant transfer.

Modelling complex groundwater flow in such fractured and karstified chalk aquifer systems therefore requires both appropriate modelling techniques and a good knowledge of local geology and discontinuities (geological and hydrogeological). This is the case for the Avre river basin, for which a numerical model was built, whose objective aims at optimizing sustainable water resource management and, more precisely in the short run, determining abstraction rates which will both satisfy local and Parisian water needs and comply with the 
minimum biological flow requirements for the Avre River, particularly in low water conditions.

This paper intends to address only some aspects of the Avre model, believed to be of particular importance in the case of modelling groundwater flow in the Normand fractured and karstified chalk environment; emphasis is essentially placed on data collection, model building and, to some extent also, on calibration results. It does not present results from water resources management scenarios for which the model has actually been built for, as this work is still ongoing.

The term "hydro-system flow model" is most often used along with the term "groundwater system flow model", both having the same meaning in this paper. However, the first term is more appropriate as one cannot dissociate groundwater flow from surface water flow and flux exchange between the two in chalk environment.

\section{The Avre river basin - general setting}

The Avre river basin is located in Eastern Normandy about $75 \mathrm{~km}$ SE from Rouen, and spreads over $975 \mathrm{~km}^{2}$ (Fig. 1). The Avre River is about $80 \mathrm{~km}$ long, flows into the Eure River at Saint-Georges-Motel, the latter being itself a left bank tributary of the Seine River. Its valley is generally bordered by a subdued topography represented by the sloping chalk cliffs of the Eure plateau which spreads over great distances outward on both sides. These bordering sloping cliffs often are entailed by wet or dry valleys, which open the horizon and sometimes bring a small tributary which can be permanent, but most often is intermittent. Main tributaries to the Avre River include from the source to the confluence the Buternay and the Meuvette. Other tributaries are small and intermittent. In addition to natural tributaries, there is a derivation canal linking the Iton River to the Avre River (flow being toward the Avre River), built in 1120 by Henry the first, Duke of Normandy, King of England and the youngest son of William the Conqueror. 


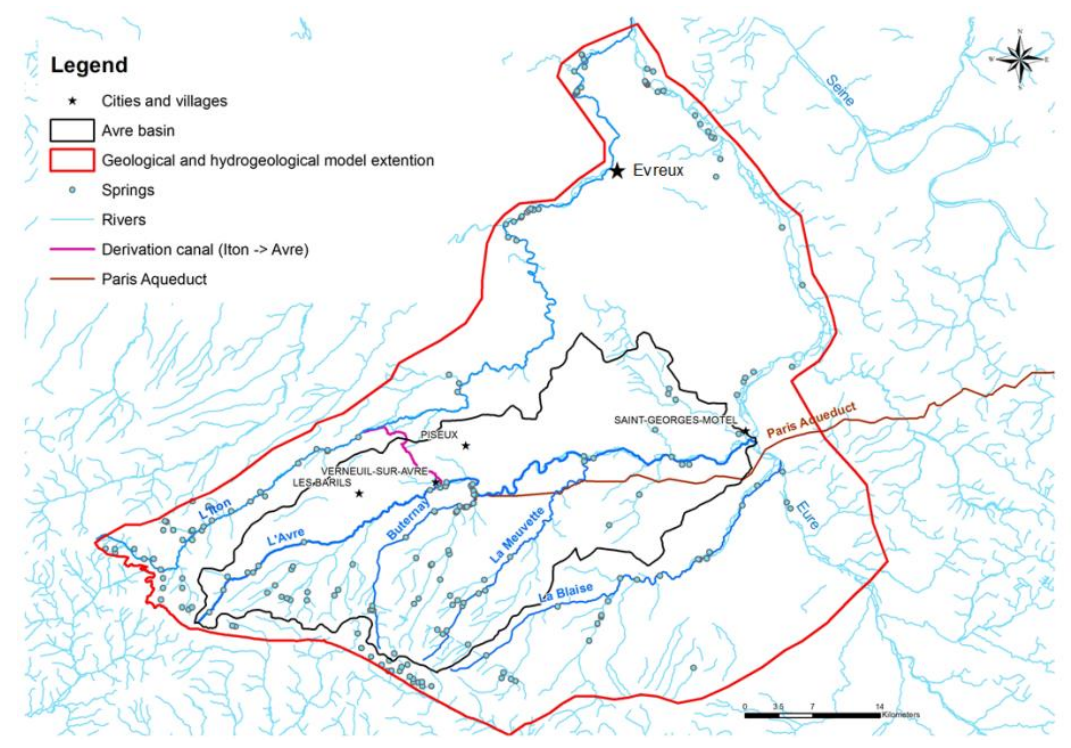

Fig. 1: General situation plan and extension (limits) of the modelled area (geological and hydro-system flow models).

The Avre basin is mostly imbedded in the chalk formations of the Paris basin, excepted in its very upstream portion where it rests on the Perche Sands. Both the chalk formations and the Perche Sands are major regional aquifers.

The Avre River basin is characterized by a mostly rural setting, with small cities and villages dispersed in the valley. Intensive groundwater pumping occurs in the chalk formations in the Avre valley ( $29 \mathrm{Mm}^{3} / \mathrm{yr}$.), mostly for drinking water purposes (> $85 \%$ of all pumping), to satisfy local needs $(\sim 16 \%$ of the pumped volumes for drinking water), but more so the Paris water needs ( $84 \%$ of the pumped volumes for drinking water). Indeed, the Paris water company is diverting a significant part of the Avre basin groundwater springs, particularly in the area of Verneuil/Avre located on the middle part of the catchment, to send it toward the Paris area via an old aqueduct built in the late nineteen century.

However, occurrences of river dry out episodes have been taken place upstream. Furthermore, fears of lacking water for local needs in the catchment have arisen. This prompted to include into the basin management scheme (SAGE) targets to secure local drinking water production and protection of the aquatic ecosystems. Better water resource management was therefore needed which lead to building the numerical model presented in this paper.

Field investigations and collecting the necessary data to build up the geological and the hydro-system flow models 
Existing data and literature were collected, analyzed and synthetized, as a first step in the study. This included gathering basic data on geology, hydrodynamic and climatic parameters, river flow, as well as data on groundwater abstraction rates and volumes of liquid wastes being returned to the aquatic medium.

From this first step of the study, it became apparent that many uncertainties remained, notably about the extent of the groundwater catchment, and more generally about the possible fit that existed or not between the river basin and the groundwater catchment. Questions emerged also about the existence of possible groundwater connections between the Avre and the Iton basins on the north side, and between the Avre and the Blaise basins on the south side (David et al. 2012).

Furthermore, it also appeared that geological aspects were relatively complex and that they might, to some extent at least, influence groundwater flow and interaction processes between groundwater and surface water, and more generally, between groundwater and the ground surface (Fig. 2). Indeed, important fault structures were known or being suspected, such as the Senonche fault upstream in the Avre basin, which puts into contact the Perche Sands and the Turonian Chalk. More important for the model, a fault structure was suspected to be passing through the Verneuil/Avre area, which could account for the major springs and resurgences (karstic springs resulting from a previous upstream river loss) found there, many of which being tapped for drinking water purposes by the Paris Water Co.

Abundance of lineament patterns in certain areas also suggested that some of them could have enhanced karst or highly fractured axes development inducing preferential groundwater flow, which could explain the results found in tracer test experiments. Finally, the extent of several geological formations and, more generally their 3D geometries, were poorly known.

All these reasons and the need to reduce the degrees of freedom for the calibration process of the groundwater model, lead to further investigation in the field and to the construction of a geological model.

Complementary investigations were carried out in the field in 2013 including (1) setting up two lines of piezometers to monitor the evolution of the groundwater divide between the Avre and the Iton basins, (2) implementing multi-tracer tests to explore possible hydraulic connections between the Avre and the Blaise basins and (3) carrying out geophysical (seismic and electric) surveys in the area of Verneuil/Avre to test the hypothesis made about the presence of a major fault structure.

Results from the field work showed that the Avre and Iton groundwater catchments may become connected during low water conditions close to Piseux, north of Verneuil/Avre, but not in the Barils area were the groundwater divide seems to be strong enough to persist during low water conditions. No connection were shown between the Avre basin and the Blaise catchment in the south, 
although doubts remain on that aspect due to the fact that water companies had imposed using very small quantities of tracers which simply could have led to below detection levels tracer concentrations in the target wells and springs.

The geophysical survey, however, demonstrated the presence of complex sets of intersecting faults systems in the Verneuil/Avre area (NW-SE and NE-SW), generally showing notable vertical displacement (10 to $30 \mathrm{~m}$ ), with impermeable characteristics in the south along the Avre and the Buternay rivers, and less so in the north. This could very well explain the observed springs and resurgences alignments found in both the Avre and Buternay valleys, as the groundwater may be forced up to the ground surface in these areas (Fig. 2). 


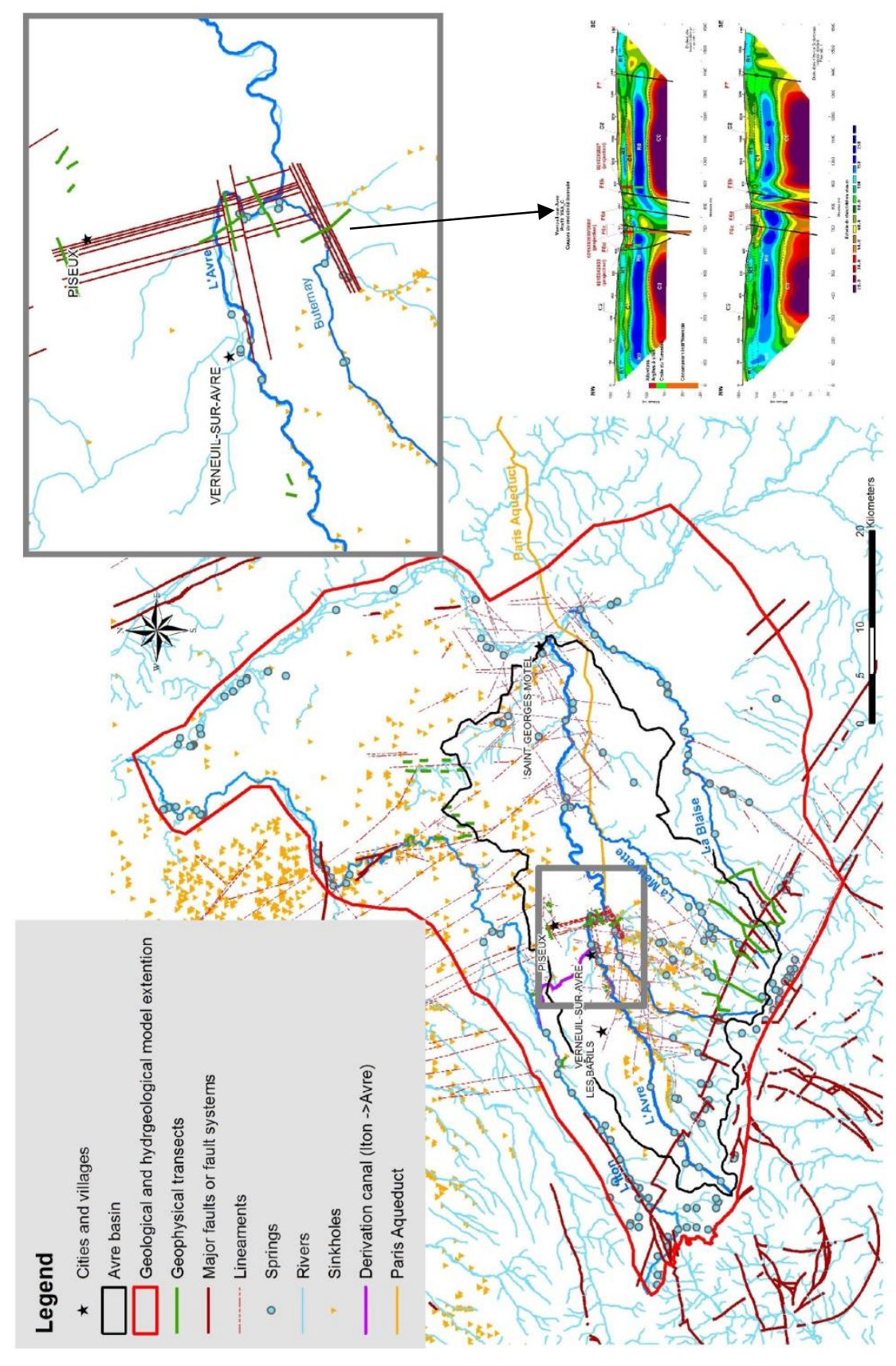

Fig 2 : Known or suspected geological/hydrogeological structures and features and zoom on the Verneuil/Avre area's complex geology and related hydrogeology 


\section{Building the geological model of the Avre basin}

In order to account as best as possible for weathered formations, horizontal and vertical geological heterogeneities, and notably to better define major geological structures (fault systems, anticlines, synclines, ...) on a regional scale, and ultimately to provide a refined realistic geometry for the aquifer reservoirs, a 3D geological model was built, as a first step in the elaboration of the hydro-system flow model..

To allow for maximum flexibility in building the groundwater system flow model, the limits of the geological model were extended far beyond the area of interest (Fig 1).

The geological model was built using all available data in different formats, such as geological logs from the BSS (French national underground data base BRGM), cross sections, known major faults, layer extent (whenever known), geological maps and geophysical data, as well as topographic maps and existing digital elevation models (DEM). It was built using BRGM's software GDMMultilayer 2014 (Bourgine 2006, Bourgine et al. 2008).

The geological model was developed based on (1) the description of geological units chronologically deposited onto one another (conformable or not), according to the appropriate lithostratigraphic framework, (2) definition of a vertical faults network, and (3) interpolation of compiled and hierarchized geological and geophysical data.

More specifically, the first step consisted in setting up the appropriate lithostratigraphic framework, keeping in mind the needs for describing groundwater flow conditions. This required adapted processing, such as regrouping geological layers showing similar characteristics or, on the contrary, in some cases separating individual layers into two distinct layers to account for partial intersection phenomena (one layer penetrating another only in some parts of the modelled area). Next steps were to set up the limits of the geological layers in the study area and to define the main faults networks that needed to be taken into consideration.

Building of the model next included assessing and coding data, defining the computing grid, insuring and testing coherence between data, and then interpolating between data (kriging), managing inequalities (known data located between layers' top and floor altitudes), setting up constraint points, and finally combining surfaces which is a process consisting in cutting up/matching up surfaces according to a deposit/erosion logic previously defined in the lithostratigraphic framework (see David et al. 2015 for more information about building the geological model). 
The resulting geological model for the Avre basin includes 11 layers (Fig. 3), of which some extend only partially over the modelled area, such as the weathered formations, notably the alluvial materials present in the valleys and the flint rich clay essentially covering the plateau areas. This is also the case for the Perche Sand, bounded by the Senonche fault, which outcrop beneath superficial deposits in the upstream most part of the basin.

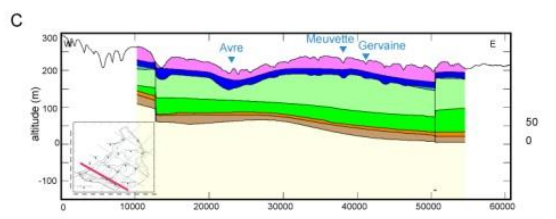

D

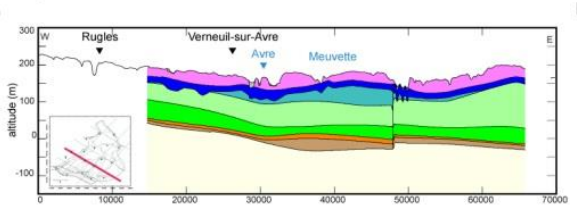

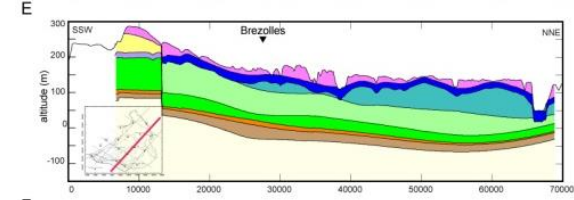

$\mathrm{F}$

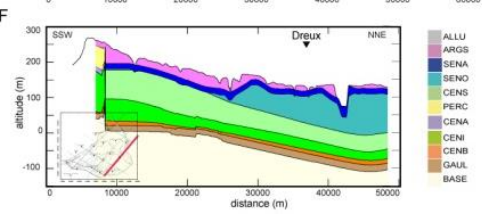

Fig 3 : Examples of 2D large scale cross sections extracted from the $3 D$ geological model (ALLU : Alluvial material, ARGS : Flint-rich clays, SENA : weathered Middle Cenomanian to Senonian Chalk, SENO : Middle and Upper Turonian and Senonian chalk, CENS : Lower Turonian and Middle to Upper Cenomanian Chalk, PERC: Perche sands, CENA : weathered lower Cenomanian, CENI : lower Cenomanian, CENB : basal Cenomanian, GAUZ : Gault clays (base of the aquifer system).

The geological model includes also two distinct layers of weathered chalk: the weathered lower Cenomanian chalk and the weathered Senonian chalk. These layers represent the upper weathered portion of the chalk where most of the groundwater flow occurs; these are therefore complementary layers and never overlap. They extend over the entire modelled area and generally range between $10 \mathrm{~m}$ to $50 \mathrm{~m}$ in thickness. These two layers were basically created to enable differentiation between flow in the upper weathered portion of the chalk aquifer and flow in the undisturbed bulk chalk, in the hydro-system flow model.

\section{Setting up the numerical hydro-system flow model of the Avre basin}

Once the geological model was set up for the area and data processing had occurred, the hydro-system flow model was built using the MARTHE computer program developed by BRGM. MARTHE uses an integrated finite difference approach (finite volumes) with implicit discretization to solve groundwater flow equations with an irregular square mesh nested grid (completely coupled nested grid pattern with simultaneous resolution). The wide panel of features it provides include $1 \mathrm{D}, 2 \mathrm{D}$ or $3 \mathrm{D}$ flow simulation and the possibility to represent differences in layers' extensions and short circuits between layers whenever a layer disappears or thins out. It also allows for taking into account free surface and overflow mesh 
in any layer, darcian and non-darcian flow, variable river flow, groundwatersurface water flux exchange and the use of watertight walls (i.e; impermeable faults). This list is far from being exhaustive and more information about MARTHE's features can be found in reference 5 (Thiery 2015).

The governing equation used by MARTHE for groundwater flow is :

$$
\begin{array}{lll}
- & \operatorname{div}(K . \operatorname{grad} H)+q=S s . \delta H / \delta t & \text { (1) confined aquifers } \\
- & \operatorname{div}(K . \operatorname{grad} H)+q=1 / d z \cdot S l . \delta H / \delta t & \text { (2) unconfined aquifers }
\end{array}
$$

With :

K : Permeability

$H \quad$ : Hydraulic head

$q \quad$ : Pumping or injection rates (yield by unit volume)

$t \quad:$ : time

Ss $\quad$ : Storage coefficient

Sl : Specific yield

The building process of the groundwater system flow model included several steps.

First, the limits of the model were set out so as to ensure maximum flexibility and prevent any kind of significant "border effect" within the Avre basin, the area of interest for which abstraction rules for sustainable water resources management will need to be determined. Indeed, analyzing collected data previously suggested that groundwater divides at the catchment borders could sometimes disappear during droughts. For that reason, in all cases, model limits were placed sufficiently far beyond the groundwater divides which are directly linked to the borders of the Avre basin. The resulting limits chosen were for most of them natural, often representing major faults (when thought to be impermeable), rivers (when draining the aquifer system) and distant groundwater divides; these in fact match the limits set out for the geological model (Fig. 1). Limits taken as major impermeable faults or distant groundwater divided were handled as no flow boundaries and those placed on draining rivers were set out to be constant heads.

Next, the above geological model was enriched and adapted according to hydrogeological needs, but also simplified to comply with computing constraints. This was done on the basis of available data, but also in a way that it would not significantly alter resulting accuracy of the hydro-system flow model. During this process, the geological model was reduced from 11 to 5 layers (Table 1). For example, the two weathered chalk layers which are contiguous were combined into one single layer of weathered chalk which extends over the entire modelled area. Properly adapting hydrodynamic properties is sufficient to account for heterogeneities in this case. The rest of the chalk was also regrouped on the basis 
of hydrodynamic properties, in two layers: one for the Cenomanian and lower Turonian chalk and, the other one, for the upper Turonian and Senonian chalk. Alluvial materials and flint-rich clays became one layer as did the weathered chalk. Gault clays and basal Cenomanian formations made up the floor of the aquifer system.

In addition, in order to better determine potential discontinuities and axes of more rapid or preferential groundwater flow which tend to characterize vast portions of the region, the geological model was enriched with three kinds of data: lineaments, alignments of sinkholes and tracer test results. These complement the fault system already included in the model.

All the known lineaments existing in the area were mapped and included in a special GIS layer (Fig. 2). Lineaments are thought to enhance preferential flow in some cases, and can develop with time to become fractured axes or karst conduits. Correlations between lineaments and results from tracer test investigations previously suggested this phenomenon.

Secondly, data available on sinkholes and tracer tests were extracted from the sinkholes and tracer tests database [6]. Statistical analyses of sinkholes distributions (the surface expression of a karst network) and correlation with results from tracer tests also helped establishing potential axes of preferential flow in the chalk aquifers. There again a GIS layer containing sinkholes data and tracer tests results was utilized (Fig. 2).

The geometry of the hydro-system flow model was next set up based on the above described simplified and enriched geological model. The vertical geometry of the hydro-system flow model included therefore 5 active hydrogeological layers (Table 1), which were set up to be hydraulically connected to each other in all the areas where they directly overlap, whichever their position was in the geological framework. The top and the bottom of each active layer are precisely located in the 3D space based on absolute topographic heights at each mesh of the grid. The basis of the aquifer system composed of the Gault clay and the lower Cenomanian formation was defined to be aquiclude.

Horizontal discretization of the layers was achieved using a variable size square mesh nested grid. This was done according to the distribution of the zones of interest (generally the Avre River valley, the well fields, the main spring and resurgence areas, the wetlands), the size and the complexity of modelled objects (i.e; potential discontinuities), the required precision and the distribution of available data (in particular, data used to control the calibration process).

All these considerations led to the model geometry summarized in table 1 . The resulting grid is for the most part finest $(100 \mathrm{~m})$ in the Avre valley along a strip about 4 to $5 \mathrm{~km}$ wide, centered on the river, where refined accuracy is needed (Fig. 6). It is also compatible with the grid defined for the geological model. 
Table 1: Summary of the groundwater system flow model general geometry and grid characteristics

\begin{tabular}{|c|c|c|c|}
\hline $\begin{array}{c}\text { Model } \\
\text { layer. }\end{array}$ & $\begin{array}{c}\text { Hydrogeological formations } \\
\text { represented }\end{array}$ & $\begin{array}{c}\text { Mesh size } \\
\text { range (m) }\end{array}$ & $\begin{array}{c}\text { Number of } \\
\text { meshes }\end{array}$ \\
\hline 1 & Alluvium and flint-rich clay & $100-500$ & 37672 \\
\hline 2 & Perche Sands & $100-500$ & 3904 \\
\hline 3 & Weathered chalk & $100-500$ & 39205 \\
\hline 4 & $\begin{array}{c}\text { Upper Turonian and Senonian } \\
\text { chalk }\end{array}$ & $100-500$ & 23015 \\
\hline 5 & $\begin{array}{c}\text { Lower Turonian and Cenomanian } \\
\text { chalk }\end{array}$ & $100-500$ & 39185 \\
\hline TOTAL & \multicolumn{2}{|c}{} \\
\hline
\end{tabular}

Before starting the calibration process, the model was first initialized with the collected data set. Notably data for the river network (river segment geometry, riverbed altitude for each segments,...), for hydrodynamic parameters in each layer of the aquifer system (permeability - horizontal, vertical, storage coefficient, specific yield, ...) and for time dependent parameters (abstraction rates, liquid wastes returned to the natural medium, natural recharge, overland flow,...) were introduced in the model so as to have a starting distribution of values for all parameters involved in the computing process. All time dependent parameter were introduced in the model as daily values. Those which were not available on a daily basis, such as abstraction rates most often, were first converted to daily values using the best possible repartition scheme (weekly abstraction curves, linear, ...) before being inserted into the model.

A few clarifications must be given here. First, the river network was included in the aquifer system flow model as a georeferenced arborescent (tree like structure) network placed on top of the hydrogeological layer closest to the ground surface. It is hydraulically connected to the latter so that flow exchange between surface and groundwater can take place as needed, according to prevailing hydraulic gradients, and to the geometry and permeability of the river bed. The river network is divided into segments through which water can flow whenever they are not dry. River segments are determined according to their characteristics (width, slope, thickness of the river bed, ...), to the distribution of control points (i.e.; gaging stations) and to the expected interactions with the underlying groundwater. River flow simulation is handled using the governing mass balance and related equations shown in Table 2):

Table 2: General principle used for river flow simulation in MARTHE (Thiery 2015) 
$Q a v=Q a m+Q e c h+Q r u i+Q i n j-d S T O / d t$

Where:

$Q_{\mathrm{av}}=$ downstream flow; $Q_{\mathrm{am}}=$ upstream flow $; \mathbf{Q}_{\mathrm{ech}}=$ groundwater/river exchange flow $; Q_{\text {rui }}=$ overland flow and overflow; $Q_{i n j}=$ source term (pumping in/out) and STO = storing yield.

$Q a v=\frac{1}{n} \cdot A \cdot R^{2 / 3} \cdot \sqrt{ }($ Slope $)$

Where :

A = Segment cross-section; $\mathbf{R}=$ Hydraulic radius $\left(\mathbf{W}_{\mathrm{idth}} \times \mathbf{H}_{\mathrm{rl}}\right) /\left(\mathbf{W}_{\mathrm{idth}}+2 \mathbf{H}_{\mathrm{rl}}\right)$; $\mathbf{n}=$ Manning-Strickler coefficient (rugosity); Slope = Slope of the river segment; $\mathbf{H}_{\mathrm{rl}}=$ Water height above the river bed; $W_{\text {idth }}=$ River width in the segment.

When small overspill dams impedes or modifies natural river flow at the downstream edge of the river segment, equation 2 is replaced by a overspill dam law, as show in equation 3.

Qav $=$ Width $x$ FactQ $x \sqrt{(2 g)} x(\text { Hrl }- \text { Hseuil })^{\mathrm{i}}$

Where :

Fact $Q=$ Unitless factor with a default value around 0,$4 ; g=$ gravitational acceleration; $H_{\text {seuil }}=$ height above the river bed of the top of the dam; $i=$ Exponent, usually taken to be 1,5.

Secondly, exchange flow between groundwater and surface water is governed by the following equation :

$$
Q=S \cdot k v \cdot \delta H / \delta z
$$

with :

$S \quad$ : Exchange surface (varies according to the hydraulic situation)

$k v \quad$ : Permeability of the river bed and banks

$\delta H / \delta z:$ Vertical hydraulic gradient

Thirdly, computation of recharge underwent a special procedure; it was computed using (1) the AURELHY grid provided by METEOFRANCE to determine 4 homogeneous meteorological zones in the Avre basin, (2) daily rainfall and evapotranspiration data from the associated representative meteorological stations and (3) a global reservoir type model, GARDENIA (Thiery 2014). GARDENIA in this case was essentially used to compute net rainfall, infiltration and overland 
flow for the different sub-basins equipped with gaging stations. Computation of these parameters notably used varying soil water storage (progressive soil reserve), infiltration retardation factors to attempt reproducing system' inertia (time of $1 / 2$ percolation), and a variable infiltration/overland flow distribution function (through infiltration/overland flow distribution coefficients). These were computed on a daily basis and introduced into the hydro-system flow model.

Finally, Springs and resurgences included in the modelled area were set out to be overflow nodes, just as it is the case for the entire topographic surface, meaning that any water which exceeds the nodes' topographic level becomes parts of the overland flow.

\section{Calibrating of the hydro-system flow model}

Calibration followed in two steps, first in steady state, based on data from the relatively dry hydrologic year 2005-2006, and next in transient state over the period 1990 - 2012. The time step used for calibration of the hydro-system flow model was the day.

The calibration process strived to reach a best fit between the computed values and the corresponding data measured in the field for the control parameters. In this case, these included piezometric maps covering part of the modelled area, and time series available for groundwater level fluctuations in individual wells, spring flow (when available) and river flow measured at the gaging stations operating in the Avre and Iton basins (the model extends partially into the Iton basin). Control data or control parameters also included data from sporadic river flow gaging campaigns. Groundwater levels, spring flow and river flow are all parameters that are computed by the model.

Calibrating the model mainly consisted in varying the values for permeability (for the aquifer layers and the various segments of the river beds), the specific yield and the 3 parameters used to compute infiltration or aquifer recharge rates and the overland flow rates (progressive soil reserves, time of $1 / 2$ percolation and infiltration/overland flow distribution coefficients). This was achieved for all parts of the modelled area, using ranges of values plausible or normally accepted for this chalk hydro-system environment.

The value of all other parameters basically remained untouched; this among others included the geological model, net rainfall, pumping rates and injection rates.

Through the calibration process, the geological model associated to the control data helped determining which lineaments represented preferential flow axes, which did not, and which major faults systems totally or partially impeded groundwater flow, and eventually were responsible for spring alignments (forcing groundwater up), and which had no impact. Indeed, rapidly in the calibration 
process, it became apparent, that some faults opposed impermeable barriers to groundwater flow, others, not, and many lineaments on the contrary needed to be treated as preferential flow axes, although others did not seem to have any significant influence.

At this stage, there was no need to introduce non darcian conduit or channel flow; preferential flow along lineaments and river valleys were simply affected by high to very high permeability values. On the other hand, watertight barriers were introduced in the hydro-system flow model were major faults or portions of major faults appear to be impermeable; these structures for which the size can be defined were inserted within the concerned set of mesh (mesh crossed by the fault).

Table 3 shows the range of values tested for the main parameters used for calibration.

Table 3 : Range of values tested for the main parameters used in the calibration process of the hydro-system flow model

\begin{tabular}{|l|l|l|l|l|l|l|}
\hline & \multicolumn{2}{|c|}{ Aquifer } & \multicolumn{2}{c|}{ River } & \multicolumn{2}{c|}{ Recharge and overland flow } \\
\hline Parameter & $\begin{array}{l}\text { Permea- } \\
\text { bility, k } \\
(\mathrm{m} / \mathrm{s})\end{array}$ & $\begin{array}{l}\text { Specific } \\
\text { yield, SI } \\
(\%)\end{array}$ & $\begin{array}{l}\text { River bed } \\
\text { /banks } \\
\text { permeability } \\
(\mathrm{m} / \mathbf{s})\end{array}$ & $\begin{array}{l}\text { Ratio } \\
\text { Infiltration } \\
\text { /Overland } \\
\text { flow }\end{array}$ & $\begin{array}{l}\text { Progressive } \\
\text { soil reserve } \\
(\mathbf{m m})\end{array}$ & $\begin{array}{l}\text { Time } \\
\text { percolation } \\
\text { (Month) }\end{array}$ \\
\hline $\begin{array}{l}\text { Range of } \\
\text { tested } \\
\text { values }\end{array}$ & $\begin{array}{l}1.10^{-7}-10^{-1} \\
5.10^{-4}-\end{array}$ & $\begin{array}{l}1.10^{-9}-5.10^{-2} \\
5.10^{-1}\end{array}$ & $0,1-100$ & $20-300$ & $0,1-80$ \\
\hline
\end{tabular}

The reader is referred to reference 8 (Serviere et al. 2016) for more information on the calibrating process.

\section{Results from the calibration process of the hydro-system flow model}

Results obtained with this combined geological and hydro-system flow modelling approach were quite satisfactory, particularly in low water conditions, and are very promising. A few examples are given in Figures 4 to 6 . On a general basis, computed groundwater levels match corresponding groundwater levels measured in the field. The same is true for spring flow and river flow, for which the model showed a good accuracy, particularly in low water conditions, the situation when water management is most critical and for which pumping rules will need to be established in order to satisfy all water uses, as well as ensuring a safe biological flow in the Avre river. 
In addition, as it was first thought, in several cases geology plays a determining role on groundwater flow and on the formation of springs and resurgences zones; in the Verneuil/Avre area, for example, the model calibration procedure strongly suggested that the southern portion of the faults system recently detected by the geophysical campaign (Fig. 2) could most probably account for the high density of springs tapped by the Paris Water Company and, more generally, for the major resurgences area which characterizes this sector. Indeed, to help matching observed and computed levels and yields in the area, it was necessary to insert an impermeable fault in the model which forced the groundwater up into the river and out of the springs. But this alone was not sufficient; introducing preferential flow (more rapid flow) along many of the lineaments was also necessary to completely account for the important spring flow observed in the area, and to manage fitting the measured and computed data for the control parameters (groundwater levels, spring flow and river flow).

Calibration results also showed generally strong interactions between groundwater and surface water (rivers and wetlands). In fact, this phenomenon can vary and become inverted along the river course and through time, according to the hydraulic gradient evolutions. However, in areas where great densities of sinkholes are found, including in the river bed, rivers most of the time loose water to the underlying aquifer system. These areas indeed are characterized by fractured or karstic conduits which extend sometimes over great distances in the subsurface of the valley, generally a few meters $(3$ to $10 \mathrm{~m}$ ) beneath the river and roughly following their course, thereby engendering dual rapid flow, above in the river bed and below in the aquifer system. The weathered chalk in these portions of the valleys required high to very hydraulic conductivity or permeability values during the calibrating process. This is the case upstream in the Avre river basin for example.

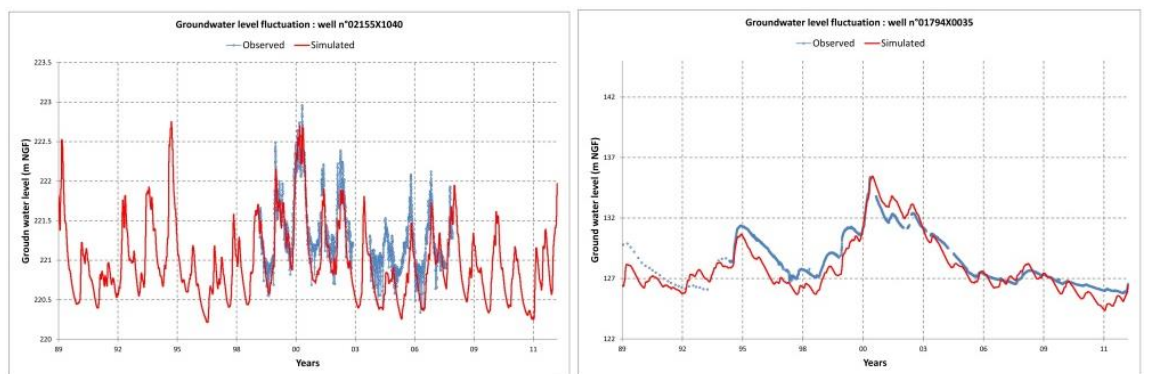

Fig 4: Model calibration results. Example of computed and measured daily groundwater levels in wells $02155 X 1040$ and $01794 X 0035$ (legend : $x$-scale in years, $y$ scale in NGF meters) 


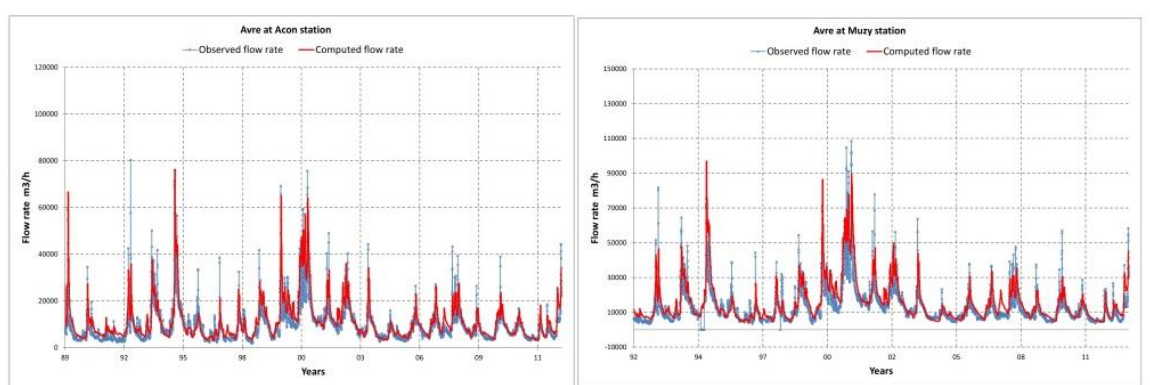

Fig. 5 : Model calibration results. Example of computed and measured daily flow rates in the Avre river at the Acon (closed to Verneuil) and Muzy (outlet of the Avre basin) gaging stations (legend : $x$-scale in years, $y$-scale in cubic meters/h) 


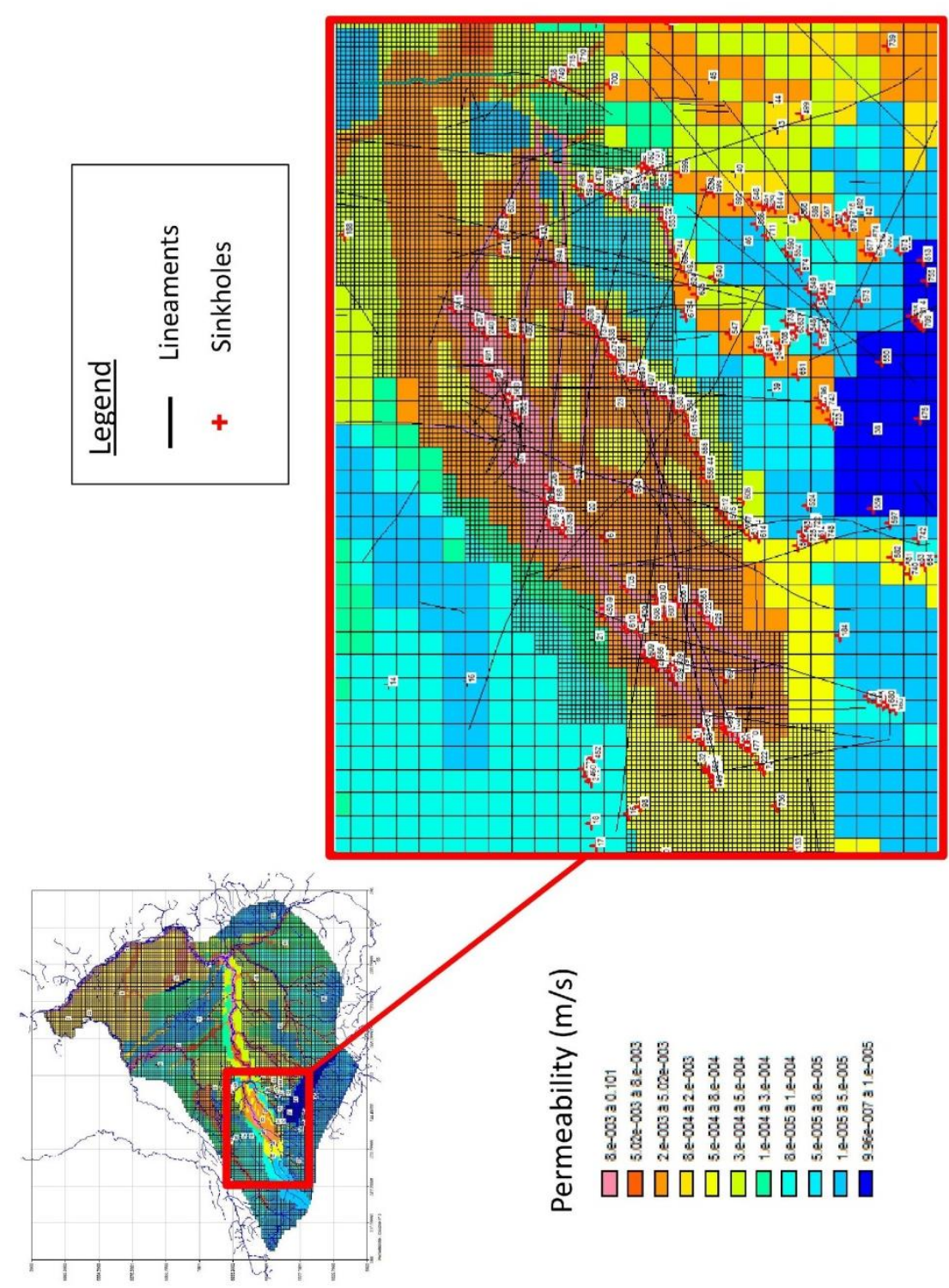

Fig 6: Model calibration results: example of permeability distribution in the weathered chalk layer (layer 3). High values are often found in karstified portions of river valleys and along fractured axes or karstic conduits developed along specific lineaments, sinkhole alignment arrays and faults. 


\section{Discussion and conclusion}

Modelling groundwater flow in the chalk environment of Normandy where dual flow often occurs (darcian/fractured and karstic), notably requires to properly define the geometry of the aquifer system, its discontinuities, its erosion features (i.e; sinkholes), as well as the geometry of the overlying river network. In fact, it is more appropriate to use the terms "modelling the hydro-system flow" as groundwater and surface water cannot be dissociated.

Building a geological model beforehand and including in it the major discontinuities and tectonic features (major faults systems, anticlines, synclines, $\ldots$ ), allows setting up the 3D geometry of the aquifer reservoirs in the most accurate way possible, and becomes a strong basis for the hydro-system flow model which follows, based on it. Furthermore, including in it secondary structures such as lineaments and erosion features, such as sinkholes, will further reinforce the building basis for the flow model. Adding to this the appropriate river network geometry allowing for river flow simulation and connecting it to the groundwater flow model, brings to the hydro-system flow model, at the same time, the necessary constraints and the needed flexibility.

This approach was applied to the Avre hydro-system flow model. Basing it on a 3D geological model helped better guiding and constraining its calibration process, making it more efficient, as the aquifer system geometry was better defined and as it allowed for directly focusing as needed on known or inferred structures, faults and lineaments, either to accelerate or increase groundwater flow along their axes to bring the necessary water to adjacent springs and resurgences areas or, on the contrary, to prevent or retard flow. Indeed, coupling the geological knowledge to water flow needs in springs and rivers, helped, to the extent of the available control data, differentiating between permeable and impermeable faults or lineaments, or between those which gave birth to karst conduits or to major fractured axes generating fast flow components in the groundwater flow field, and, those, on the contrary, which opposed a partial or a fully watertight barrier to ground water flow, as it is the case in the Verneuil/Avre region where a major impermeable fault system forces the groundwater up to the ground surface to form the springs and resurgences arrays observed there. This area in fact is probably the most sensitive one in the Avre basin, as a lot of spring water is being tapped there to be sent out to the Paris area for drinking water purpose.

The importance of geology and erosion features became apparent early in the calibration process. Although many features seemed to have no significant or little impact on the subsurface flow pattern at the scale of the model, probably also due to a lack of control data in some cases, some definitely had a major impact, driving and conditioning the flow field. 
Preferential flow in these areas has been dealt with high to very high permeability; this seemed to be rather sufficient as the karst conduits in the area usually are relatively small and the mesh size used for the model, relatively wide compared to the diameter of the karst conduits. Moreover, many so inferred karst conduits could in fact be intensely fractured axes linked to geological structures. Finally, the main objective of the model is to determine abstraction volumes at scales largely exceeding the day (the week or the month), and particularly in low water conditions.

It is felt that this combined approach (modeling geology and the hydro-system) often allows for obtaining more realistic values for the various parameters of the hydro-system flow model, as the underground and surface reservoir geometries are better defined, the fast flow vectors of the groundwater most often follow more realistic pathways and as the links between discontinuities and surface expressions (spring arrays, ...) can be more readily established ; at the end, a better and more performant flow model is often built, closer to the reality it is supposed to simulate. 


\section{References list :}

1 David, P.Y (2012) - Elaboration d'un outil de gestion des prélèvements d'eau sur le bassin de l'Avre : phase 1 : état des connaissances et phase 2 : Analyse des données - rapport final. Rapports BRGM/RP-60458-FR, 204 p., 122 ill., 7 ann.

2 Bourgine B. (2006) - Modélisation géologique 3D à l'aide du programme MultiLayer - Version 3 - Rapport technique. BRGM/RP-53111-FR

3 Bourgine B., Prunier-Leparmentier A-M., Lembezat C., Thierry P., Luquet C. and Robelin C. (2008) - Tools and methods for constructing 3D geological models in the urban environment. The Paris case., Proceeding of the Eighth international Geostatistics congress, J.M. Ortiz and X. Emery Editors, Vol 2, pp. 951-960.

4 David P.Y, Loiselet C., Pannet P., Matthieu F, Lasseur E. et Servière M. (2015) - Modélisation hydrodynamique du bassin versant de l'Avre - Phase 3 : Acquisition de données complémentaires - Phase 4 a : Construction du modèle géologique. Rapport BRGM/RP-64817-FR. 135 p., 53 ill., 6 ann.

5 Thiery D. (2015) - Code de calcul MARTHE Modélisation 3D des écoulements dans les hydrosystèmes, Notice d'utilisation de la version 7.5. Rapport BRGM/RP-64554-FR

6 David P-Y. (2012) - Inventaire régional Haute-Normandie des bétoires, trajets souterrains des eaux (traçages) et des exutoires - Rapport final d'année 4 et synthèse des 4 années. Rap. BRGM/RP-61691-FR, 128 p., 44 ill., 9 ann.

7 Thiéry D. (2014) - Logiciel GARDÉNIA, version 8.2. Guide d'utilisation. BRGM/RP-62797-FR, 126 p., 65 fig., 2 ann.

8 Servière M., David P.Y., Amaroui N. et Pennequin D. (2016) - Elaboration d'un outil de gestion des prélèvements d'eau sur le bassin de l'Avre. Phase 4b : Construction et calage du modèle hydrogéologique. Phase 5 : Elaboration de règles de gestion volumique. Rapport BRGM/RP-64826-FR. 